\title{
Genetic Diversity, Reassortment, and Recombination in Alfalfa mosaic virus Population in Spain
}

\author{
María Bergua, Marisol Luis-Arteaga, and Fernando Escriu
}

Unidad de Sanidad Vegetal, Centro de Investigación y Tecnología Agroalimentaria de Aragón (CITA), Av. Montañana, 930,50059 Zaragoza, Spain.

Current address of M. Bergua: Department of Plant Pathology, University of Florida, Gainesville 32611-0680.

Accepted for publication 22 April 2014.

\begin{abstract}
Bergua, M., Luis-Arteaga, M., and Escriu, F. 2014. Genetic diversity, reassortment, and recombination in Alfalfa mosaic virus population in Spain. Phytopathology 104:1241-1250.

The variability and genetic structure of Alfalfa mosaic virus (AMV) in Spain was evaluated through the molecular characterization of 60 isolates collected from different hosts and different geographic areas. Analysis of nucleotide sequences in four coding regions- $\mathrm{P} 1, \mathrm{P} 2$, movement protein (MP), and coat protein (CP) - revealed a low genetic diversity and different restrictions to variation operating on each coding region. Phylogenetic analysis of Spanish isolates along with previously reported AMV se-

I, IIA, and IIB for MP and CP regions. No clustering was observed for the P2 region. According to restriction fragment length polymorphism analysis, the Spanish AMV population consisted of seven haplotypes, including two haplotypes generated by reassortment and one involving recombination. The most frequent haplotypes (types for P1, MP, and CP regions, respectively) were I-I-I (37\%), II-IIB-IIB (30\%), and one of the reassortants, II-I-I (17\%). Distribution of haplotypes was not uniform, indicating that AMV population was structured according to the geographic origin of isolates. Our results suggest that agroecological factors are involved in the maintenance of AMV genetic types, including the reassortant one, and in their geographic distribution.
\end{abstract} quences showed consistent clustering into types I and II for P1 and types
Alfalfa mosaic virus (AMV) is the unique member of the genus Alfamovirus within the family Bromoviridae. AMV has a tripartite single-stranded positive-sense genomic RNA. RNAs 1 and 2 are monocistronic and encode the replicase proteins $\mathrm{P} 1$ and $\mathrm{P} 2$, respectively. $\mathrm{P} 1$ contains an $\mathrm{N}$-terminal methyltransferase-like domain and a C-terminal helicase domain, whereas $\mathrm{P} 2$ contains a polymerase-like domain. RNA3 is dicistronic; its 5'-proximal half encodes the movement protein (MP), required for cell-to-cell transport of the virus, and its $3^{\prime}$-proximal half encodes the coat protein $(\mathrm{CP})$, a structural protein involved in genome activation, replication cycle, and cell-to-cell movement, which is translated from the subgenomic RNA4 (6). AMV occurs worldwide and infects naturally over 165 host species, mainly in the Fabaceae and Solanaceae families, including economically important crops such as alfalfa, its main natural host, and tomato and pepper among vegetables (14). AMV is seedborne in alfalfa and is also transmitted by $>25$ aphid species in a nonpersistent manner (28), being a highly prevalent virus in alfalfa with large potential of spreading. Consequently, as a perennial crop, alfalfa becomes a significant reservoir of inoculum and a risk for other adjacent, susceptible crops $(32,50,66)$. Thus, knowledge of the ecological factors that underlie the AMV pathosystem and influence the epidemiology of AMV has an obvious practical and scientific interest.

The relative influence of ecological factors related to the plant hosts, transmission by vectors, and agricultural practices on the epidemiology of plant viruses may be inferred from their role as

\section{Corresponding author: F. Escriu; E-mail address: fescriu@ aragon.es}

* The $\boldsymbol{e}$-Xtra logo stands for "electronic extra" and indicates that the online version contains three supplemental tables.

http://dx.doi.org/10.1094/PHYTO-11-13-0309-R

(C) 2014 The American Phytopathological Society determinants of the genetic composition and structure of virus populations, which are often associated with evolutionary forces such as mutation, genetic exchange, migration, selection, and genetic drift $(23,24,46,49)$. For AMV and despite its significance, knowledge of the diversity and genetic structure of its populations is scarce and only a few studies provide information on the variability among isolates, based on host range assays $(10,44,45)$, serological analysis (4), amino acid composition (33), or nucleotide sequence of the CP gene $(58,75)$. These two latter studies were phylogenetically oriented and allowed the subdivision of AMV isolates into different groups, revealing an association between groups and geographic origin of isolates. However, these molecular studies were based on a limited number of isolates, with little focus on the genetic structure of AMV populations, which, to our knowledge, has not been studied in depth before.

Alfalfa has a significant economic impact in Spain (16), particularly in the Ebro Valley (northeastern Spain), where $>50 \%$ of Spanish alfalfa production is generated. AMV is widespread in Spanish alfalfa crops $(5,11,13)$ and it is also frequently found infecting vegetable crops such as pepper (39), tomato (59), borage (40), and lettuce or brassica crops (48). Here, we analyze the genetic diversity and population structure of AMV, based on a collection of 60 isolates from different hosts and different areas of Spain, and compare them with previous AMV genetic information from up to 112 isolates from other parts of the world. Our results reveal the presence in Spain of three phylogenetic types and haplotypes originated from mixed infection, reassortment, and recombination. One of the reassortants is significantly frequent and is maintained in the population. Results also confirm the geographic distribution of AMV genetic types at world scale and, interestingly, also at regional scale. The maintenance of genetic types and their geographic distribution is probably associated with agroecological factors that differentiate the areas under study. 


\section{MATERIALS AND METHODS}

Virus isolates. AMV isolates analyzed in this study were collected from 2005 to 2007 in commercial alfalfa fields or belonged to the virus collection maintained in our laboratory, obtained from 1981 to 2007 from the field. Samples were collected in 16 different locations belonging to the provinces of Huesca and Zaragoza in the Ebro Valley (EV; central-eastern Spain), Badajoz and León (BAD and LE; central-western Spain), and Gerona in Ampurdán (AM; coastal northeastern Spain). Plant host species included alfalfa (Alf), tomato $(\mathrm{T})$, pepper $(\mathrm{P})$, faba bean $(\mathrm{Hb})$, borage (Bo), and the weeds Solanum nigrum L. (S.n), Trifolium repens L. (T.r), Chenopodium album L. (C.a), Convolvulus sepium L. (C.s), Sonchus oleraceus L. (S.o), Picris echioides L. (P.e), and Malva sylvestris L. (M.s). Isolates derived from a single field-infected plant and were identified here using a code (i.e., Alf-6-07.AM) that refers to the original host, sample number, year of collection, and geographic origin. AMV reference strains $425 \mathrm{~L}$ and YSMV were generously provided by J. F. Bol and L. Neeleman (Institute of Biology, Leiden University, The Netherlands). Isolates were propagated in Nicotiana clevelandii Gray, N. glutinosa L., N. tabacum L. 'Xanthi nc', and Physalis floridana Rydb to get high viral titer. When local-lesion biological cloning was attempted, isolates were inoculated onto Vigna unguiculata (L.) Walp and subsequently propagated in $N$. clevelandii. Total RNA was extracted as described by Escriu et al. (15) from $0.2 \mathrm{~g}$ of systemically infected leaves in $400 \mu \mathrm{l}$ of extraction buffer $(100 \mathrm{mM}$ Tris- $\mathrm{HCl}$ [pH 8.0], $10 \mathrm{mM}$ EDTA, and $2 \%$ sodium dodecyl sulfate) and $400 \mu \mathrm{l}$ of a mix of phenol/chloroform (2:1), and precipitated in $2 \mathrm{M} \mathrm{LiCl}$ at $4^{\circ} \mathrm{C}$ for 12 to $16 \mathrm{~h}$.

Genetic characterization of viral isolates. The nucleotide sequence was determined after reverse-transcription polymerase chain reaction (RT-PCR) amplification of four genomic regions included in the open reading frames (ORFs) of the proteins P1 (RNA1), P2 (RNA2), MP, and CP (RNA3). The following pairs of primers, designed according to conserved motifs in alignments of AMV sequences available at that moment in GenBank, were used for amplifications. They are identical and complementary, respectively, to the indicated nucleotides in the genome of AMV-425L (accession numbers L00163 for RNA1, X01572 for RNA2, and K03542 for RNA3): RNA1-F (5'-GTTTTTATCTTACACA CGCTTGTG-3') and RNA1-R (5'-GTAATTTGACGCATCA ATGGC-3'), nucleotides 1 to 24 and 1,910 to 1,930 in RNA1; RNA2-F (5'-GTTTTTATCTTTTCGCGATTG-3') and RNA2-R (5'-GGCCGTTCTAGGTGCAGAG-3'), nucleotides 1 to 21 and 1,436 to 1,454 in RNA2; MP-F (5'-GCTGAGGAAATGTTA CTAGC- $\left.3^{\prime}\right)$ and MP-R (5'-GCATTTAAGAGATCGCGG-3'), nucleotides 415 to 434 and 958 to 977 in RNA3; and CP-F (5'GTGTGGCAAAGCC-3'); and CP-R (5'-CAGTAATCAAACT GC-3'), nucleotides 1,457 to 1,469 and 1,908 to 1,922 in RNA3. Total RNA was primed with random hexamers (Invitrogen), and M-MLV Reverse Transcriptase (Promega Corp.) and Taq DNA polymerase (Invitrogen) were used for RT-PCR amplifications. PCR cycling conditions were as follows: 33 cycles with denaturation for $45 \mathrm{~s}$ at $94^{\circ} \mathrm{C}$; annealing for $30 \mathrm{~s}$ at $50^{\circ} \mathrm{C}$ (RNA1), $55^{\circ} \mathrm{C}$ (RNA2), or $53^{\circ} \mathrm{C}$ (MP and $\mathrm{CP}$, RNA3); and extension for 2 min at $72^{\circ} \mathrm{C}$. PCR products were purified using the Illustra GFX PCR DNA Purification Kit (GE-Healthcare). PCR fragments were used as template for the determination of the consensus nucleotide sequences in an ABI PRISM DNA automatic sequencer (Perkin-Elmer). The GenBank/EMBL/DDBJ accession numbers for the sequences of the P1 (RNA1), P2 (RNA2), MP, and CP (RNA3) genes reported in this article are JQ691297 to JQ691356, JQ691237 to JQ691296, JQ691117 to JQ691176, and JQ691177 to JQ691236, respectively.

For restriction fragment length polymorphism (RFLP) analysis, RT-PCR products of 563 and 466 nucleotides (nt) were amplified as described above from the MP and $\mathrm{CP}$ regions, respectively. In the $\mathrm{P} 1$ region, the primer RNA1-RFLP-F (5'-CAGTCCATAGC GACTATG-3'), identical to nucleotides 1,253 to 1,270 in RNA1 of AMV-425L, was used in combination to RNA1-R to amplify a 678-nt product, which corresponded to the sequenced region. PCR products ( $5 \mu \mathrm{l}$ each) were digested in separate reactions with 5 to $20 \mathrm{U}$ of $T s p$ RI, DdeI, AvaII, or SfaNI (New England Biolabs) for $3 \mathrm{~h}$ at the temperature recommended by the manufacturer. After digestion, the fragments were separated by electrophoresis in $2 \%$ agarose gels and stained with ethidium bromide (62).

Nucleotide sequence analysis and statistics. Multiple nucleotide sequence alignments were obtained using ClustalX (71) with the default parameters. Pairwise genetic distances among sequences were calculated by the Kimura's two-parameters method (31) and the PBL method $(35,55)$ and expressed as nucleotide substitutions per site. Mean nucleotide diversities for P1, P2, MP, and $\mathrm{CP}$ regions were estimated from genetic distances and compared using the nonparametric Wilcoxon test, and their standard errors were calculated using the bootstrap method with 1,000 replications (53). The direction and degree of selective constraints operating in a coding region was assessed by the ratio between nucleotide diversities at nonsynonymous and synonymous positions (dNS/dS) (76). Phylogenetic analyses were inferred by the neighbor-joining method (61) from Kimura's genetic distances and by the parsimony method (18). Robustness of phylogenetic relationships was assessed by 1,000 bootstrap replications. Software for genetic distance calculation and phylogenetic analysis was implemented in MEGA v.4.0 (67). Withinpopulation and between-population nucleotide diversities were estimated from genetic distances as described by Nei (52). The degree of genetic subdivision of AMV population was measured with the statistic $K_{\mathrm{ST}}(29)$. Hypothesis testing for $K_{\mathrm{ST}}$ was based on the distribution of the statistic when calculated 1,000 times from the random assignation of sequences to the different subpopulations under the null hypothesis of no genetic differentiation. The null hypothesis was rejected when the probability of obtaining either the observed $K_{\mathrm{ST}}$ or a more extreme value was $<5 \%$ (i.e., $K_{\mathrm{ST}}$ value close to 1) (29). Calculation of $K_{\mathrm{ST}}$ and its statistical significance was implemented in DnaSP v5 software (36).

Likely events of reassortment and recombination were detected using RDP, GENECONV, Chimaera, MaxChi, BOOTSCAN, and SISCAN methods implemented in the RDP3 program (42), using the default parameters and a Bonferroni corrected $P$ value cut-off of 0.01 .

\section{RESULTS}

Genetic diversity of the Spanish population. The genetic diversity of the Spanish AMV population was estimated based on a collection of 60 isolates by comparing their nucleotide sequences in four regions covering $25.4 \%$ of the AMV genome, which were randomly selected from the genes that code for the P1, P2, MP, and CP proteins. Genetic diversity differed significantly among these regions (Table $1, P<0.05$ in a Wilcoxon test), with $\mathrm{P} 2$ and $\mathrm{P} 1$ being the regions with lower diversity and MP and $\mathrm{CP}$, both in the RNA3, the regions with higher diversity. These regions were also undergoing different degree of negative selection against amino acid changes, according to the ratio between dNS and dS positions, which was $<1$ for all of them (Table 1). The MP was the most constrained protein, even more than the less variable P1 and P2, despite the fact that it showed the highest value of $\mathrm{dS}$. The least constrained protein was the $\mathrm{CP}$, with the highest value of dNS.

Phylogenetic analysis of the AMV isolates. The phylogenetic relationship among the sequences of the 60 Spanish isolates and sequences of other AMV isolates available in GenBank (accession numbers in Supplemental Table 1), including strains $425 \mathrm{~L}$, 
YSMV, VRU, and 15/64 as references, was reconstructed for the four genomic regions using neighbor-joining and maximum-parsimony methods. For each region, relationships among sequences were the same regardless the phylogenetic method used, so that only neighbor-joining trees are shown. Two consistent clusters were apparent for the P1, MP, and CP regions (Fig. 1), whereas no significant genetic subdivision was found for the $\mathrm{P} 2$ region (data not shown). We considered type I the group of sequences that include strain $425 \mathrm{~L}$ and type II the group formed by the rest of sequences. In addition, for the MP and CP regions, type II split into two additional subgroups (Fig. 1B and C). Type IIA was defined as the subgroup including strains VRU and 15/64 and type IIB the subgroup including the rest of sequences. Genetic subdivision into types I, IIA, and IIB was further confirmed by within-type nucleotide diversities $(0.0232$ and 0.0110 for types I and II in the P1 region; 0.0283, 0.0248, and 0.0117 and 0.0235, 0.0380 , and 0.0120 for types I, IIA, and IIB, respectively, in the $\mathrm{MP}$ and $\mathrm{CP}$ regions), which were significantly lower $(P<0.001)$ than the corresponding between-type nucleotide diversities ( 0.0360 between types I and II in the P1 region; 0.0591, 0.0551, and 0.0383 and $0.0652,0.0622$, and 0.0465 between types I-IIA, I-IIB, and IIA-IIB, respectively, in the MP and CP regions).

We also examined the alignments of amino acid sequences deduced from P1, MP, and CP partial genes to identify residues representative of each phylogenetic type (Table 2). In the fragment of the $\mathrm{P} 1$ protein analyzed here (positions 360 to 587 of 1,126 total amino acids, numbers according to AMV strain $425 \mathrm{~L}$ ), two amino-acid substitutions were found in close positions (501 and 504), which discriminate between sequences of types I and II. In the fragment of the $\mathrm{CP}$ (positions 56 to 185 of 221 total amino acids), three amino-acid changes (positions 67, 84, and 94) distinguished types IIA and IIB from type I, and another one separated type IIB from types I and IIA (position 87). Changes in two additional positions (93 and 176) were associated with the segregation of type IIB from type I whereas, in these positions, sequences of type IIA shared identical residues with either type I or type IIB. However, in the analyzed fragment of the MP (positions 31 to 186 of 300 total amino acids), and despite the significant divergence into genetic types I, IIA, and IIB detected by phylogenetic analysis of nucleotide sequences, no amino acid residues were observed that fully correlated with these types, other than an arginine at position 72 found in 20 of the 24 sequences of type IIB (not shown).

Identification of haplotypes in the Spanish AMV population. Haplotypes present in the Spanish AMV population (the set of genetic types for the three genomic regions that showed phylogenetic divergence, $\mathrm{P} 1-\mathrm{MP}-\mathrm{CP}$ in that order, which are part of a same individual), including possible mixed infections, were identified by RFLP analysis of the RT-PCR products of 678, 563, and $466 \mathrm{nt}$ obtained for the P1, MP, and CP coding regions, respectively. To that end, the sequence alignments used for phylogenetic analysis were screened for restriction sites that generated digestion patterns representative of each phylogenetic type. When possible, two different restriction endonucleases were selected for each coding region. Isolates P-31-82.BAD, P-46-02.EV, and P-
62-84.EV were selected as representatives of haplotypes I-I-I, IIIIA-IIA, and II-IIB-IIB (see definition of haplotypes above), respectively, after five passages of biological cloning. For most of the Spanish AMV isolates, along with strains 425L and YSMV, digestion of $\mathrm{P} 1$ product with $T s p \mathrm{RI}$, MP product with $D d e \mathrm{I}$, and $\mathrm{CP}$ product with AvaII and $S f a \mathrm{NI}$ allowed the identification of the same genetic types as previously determined by phylogenetic analysis (Fig. 2). In a few cases, unexpected RFLP patterns were confirmed by inspection of restriction sites in the corresponding nucleotide sequences. In all cases, RFLP patterns allowed the unequivocal identification of the presence or absence of mixed infections of different genetic types in the field samples. Only isolates Alf-8-05.EV and P.e-1-06.EV showed evidence of mixed infections, which was apparent from $T s p$ RI, DdeI, and AvaII restrictions by the superposition of the corresponding single infection patterns (Fig. 2A to C). However, from SfaNI restriction, it was impossible to distinguish between patterns I* (for half of sequences of type I) and IIA; therefore, either could be present in both mixed infections in addition to type IIB (Fig. 2D). Double restriction with AvaII plus $S f a$ NI clearly indicated the presence of the three types (Fig. 2E). Accordingly, isolates Alf-8-05.EV and P.e-1-06.EV showed haplotypes II-IIA-(I+IIA+IIB) and (I+II)(I+IIB)-(I+IIA+IIB), respectively. Attempts were made for the biological cloning of both isolates and subsequent analysis by RFLP. Clones obtained from isolate Alf-8-05.EV showed haplotypes II-IIA-IIA (four clones) and II-IIA-I (two clones). No clone was recovered with type IIB in the CP region (not shown). Unfortunately, biological cloning of isolate P.e-1-06.EV failed, and it was not further characterized.

The haplotype of isolate Alf-8-05.EV suggests that sequences of recombinant nature in the RNA3 should be present in its mixed infection. Moreover, according to the phylogenetic and RFLP analyses, 15 isolates could be originated by reassortment of genome segments (Fig. 1). To confirm a recombinant or reassortant origin of these isolates, sequence alignments of the P1, MP, and $\mathrm{CP}$ regions of the Spanish isolates (except P.e-1-06.EV) along with four AMV sequences available from GenBank were concatenated in a single alignment and analyzed using RDP, GENECONV, Chimaera, MaxChi, BOOTSCAN, and SISCAN methods (RDP3 software). Significant signals of recombination or reassortment supported by at least three different methods were identified within RNA3 of Alf-8-05.EV and between RNA1 and RNA3 of 14 of the 15 isolates showing phylogenetic incongruence (Table 3). Reassortment did not have good support for isolate Alf-14-05.EV when either P1-MP-CP or P1-MP concatenated alignments were analyzed. In contrast, when the MP sequence was excluded from the analysis ( $\mathrm{P} 1-\mathrm{CP}$ alignment), the reassortment signal was well supported $(P<0.001)$ by programs BOOTSCAN, MaxChi, Chimaera, and SISCAN, probably due to the fact that its MP sequence (haplotype II-I-I) was distantly related to the rest of sequences of type I (Fig. 1B, phylogenetic tree). Thus, isolate Alf-14-05.EV was finally considered to be a reassortant between RNA1 and RNA3.

Genetic structure of the Spanish AMV population. Seven different haplotypes were identified in the Spanish AMV popu-

TABLE 1. Nucleotide diversity of the Spanish Alfalfa mosaic virus population for the P1, P2, movement protein (MP), and coat protein (CP) genomic regions ${ }^{\text {a }}$

\begin{tabular}{|c|c|c|c|c|}
\hline Genomic region $^{b}$ & $\mathrm{D}$ & $\mathrm{dNS}$ & $\mathrm{dS}$ & $\mathrm{dNS} / \mathrm{dS}$ \\
\hline P1 & $0.0264(0.0037)$ & $0.0073(0.0024)$ & $0.0672(0.0105)$ & 0.109 \\
\hline $\mathrm{P} 2$ & $0.0153(0.0020)$ & $0.0053(0.0017)$ & $0.0345(0.0065)$ & 0.154 \\
\hline MP & $0.0381(0.0060)$ & $0.0109(0.0045)$ & $0.1150(0.0242)$ & 0.095 \\
\hline $\mathrm{CP}$ & $0.0377(0.0059)$ & $0.0198(0.0058)$ & $0.0813(0.0184)$ & 0.243 \\
\hline Concatenated & $0.0277(0.0021)$ & $0.0097(0.0017)$ & $0.0699(0.0067)$ & 0.139 \\
\hline
\end{tabular}

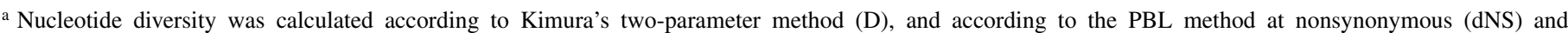
synonymous (dS) positions. Diversities are expressed as the mean number of nucleotide substitutions per site. Numbers in parenthesis are standard errors.

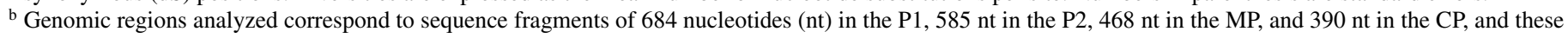
four fragments concatenated.
} 

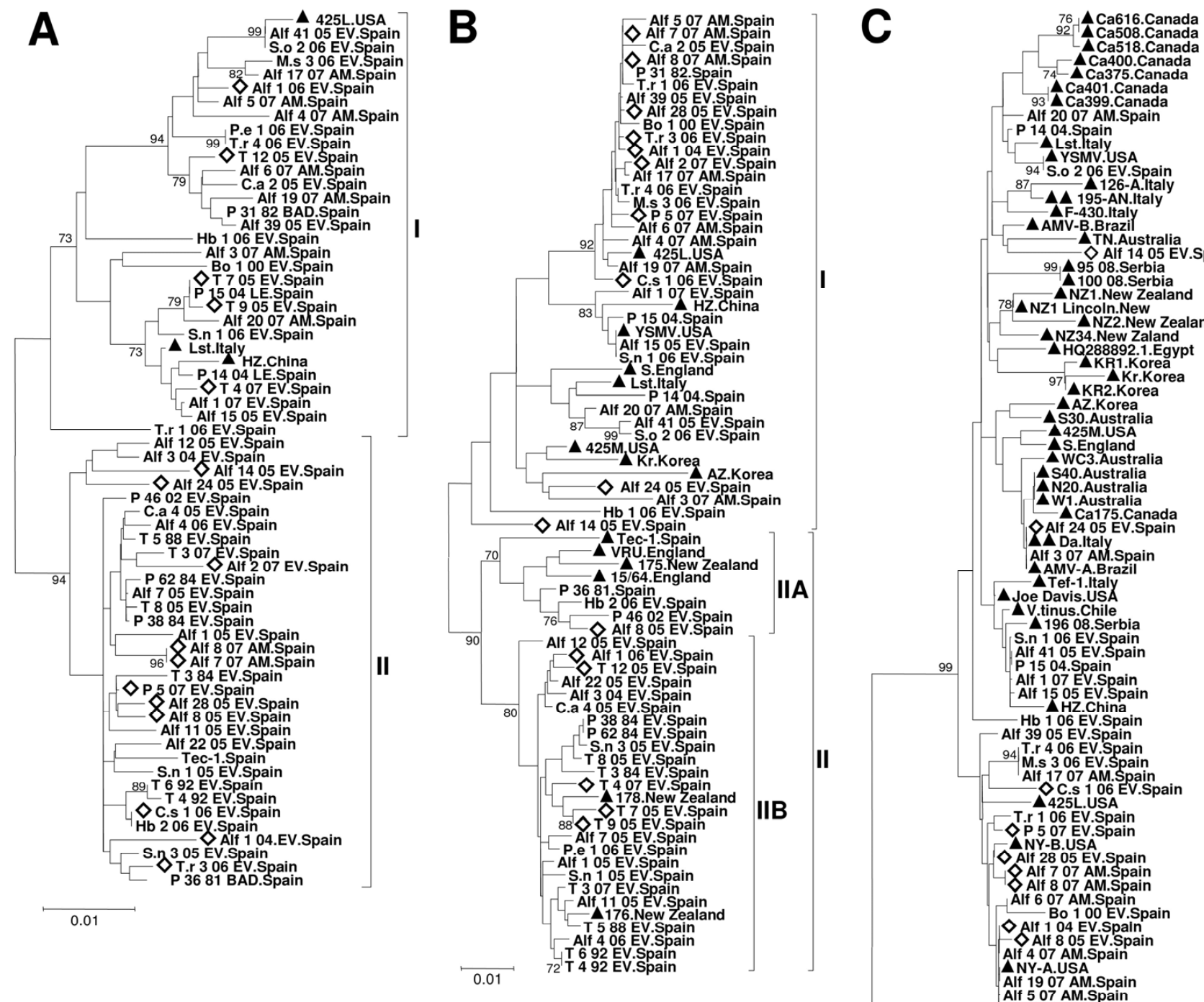

$\checkmark$ Alf 1405 EV.Spain

99 A5 08.Serbia

$\triangle$ NZ1.New Zealand

8 $\triangle$ NZ1 Lincoln. New

NZ NZ2.New Zealand

NHQ288892.1.Egypt

KKR1.Korea

${ }^{97} \mathbf{A K R 2 . K o r e a}$

425M.USA

AS. England

S40.Australia

N20.Australia

$\Delta$ W1.Australia

$\checkmark$ Alf 2405 EV.Spain

Alf 307 AM. Spain

AMV-A.Brazil

A Tef-1.Italy

$\Delta$ V.tinus.Chile

A196 08 .Serbia

S.n 106 EV.Spain

Alf $4105 \mathrm{EV}$.Spain

P 15 04.Spain

Alf 107 EV.Spain

Alf 1505 EV.Spain

Hb 106 EV.Spain

T.r 406 EV.Spain

M.s 306 EV.Spain Alf 1707 AM.Spain

425L.USA

T.r 106 EV.Spain

NY-B.USA

$\triangle$ Alf $2805 \mathrm{EV}$.Spain

$\checkmark$ Alf 707 AM.Spain

8 Alf 807 AM.Spain

Alf 607 AM.Spain

$\checkmark$ Alf 104 EV.Spain

Alf Alf 805 EV.Spain

NY-A.USA

Alf 1907 AM.Spain

Alf 507 AM.Spain

C.a 205 EV.Spain

SAlf 207 EV.Spain

P 3182 Spain

$\Delta$ TM2.Spain

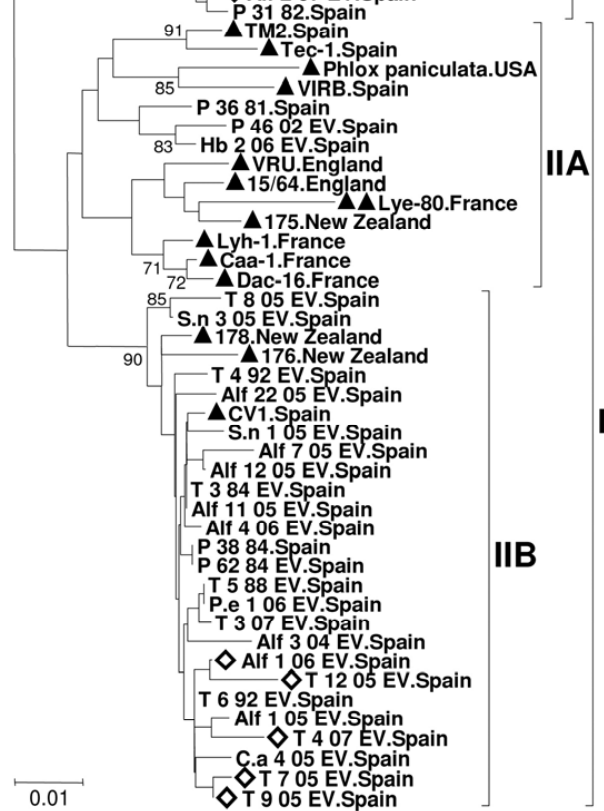

Fig. 1. Phylogenetic relationships for the sequences of A, 684 nucleotides (nt) of the P1; $\mathbf{B}, 468 \mathrm{nt}$ of the movement protein; and $\mathbf{C}, 390 \mathrm{nt}$ of the coat protein genes of Alfalfa mosaic virus isolates reconstructed by the neighbor-joining method. Support for nodes $>70 \%$ in a bootstrap analysis with 1,000 replications is shown. Names of Spanish sequences indicate the host, sample number, year, and geographic area of isolate collection (see Materials and Methods). Putative reassortant or recombinant sequences are marked $(\diamond)$. Sequences obtained from GenBank are marked $(\boldsymbol{\Delta})$, indicating the country of origin, and those of tomato isolates are also shown in $\mathrm{C}(\boldsymbol{\Delta} \boldsymbol{\Delta})$. 
lation. The distribution of its 60 isolates according to their haplotype and their host and geographic origin is shown in Table 4. Haplotypes with genetic types I (haplotype 1) and II (haplotypes 2 and 3) were equally frequent and, together, represented $72 \%$ of the population ( 37 and $35 \%$, respectively). However, most of the isolates belonging to the genetic type II showed type IIB (haplotype 3) rather than type IIA (haplotype 2) in the MP and CP regions. Haplotypes 4 and 5 were reassortants between RNA1 and RNA3 and, together, comprised $25 \%$ of the population. However, haplotype 4 was twice as frequent as haplotype 5 and it was found in a larger number of hosts and geographic areas, similar to haplotypes 1 and 3, suggesting that it is maintained in the population. Haplotypes 6 and 7 corresponded to mixed infections and, together, represented $3 \%$ of the population. Both haplotypes entail recombination to occur in RNA3. However, only recombination in haplotype 6 was confirmed, as described above.

To examine whether the Spanish AMV population showed evidence of genetic structure, a group of at least three isolates from the same host species (57 isolates distributed in four subpopulations: alfalfa, pepper, tomato, and weeds) or geographic origin (56 isolates distributed in two subpopulations: the Ebro Valley and Ampurdán) was considered to be a well-represented subpopulation. Genetic diversity in the three coding regions was calculated for these subpopulations, and the degree of genetic differentiation among them was measured by the statistic $K_{\mathrm{ST}}$. Subpopulations divided according to the original host showed similar within- and between-subpopulation diversities for the P1 region, indicating no genetic differentiation (data not shown). For the MP and CP regions, however, within-subpopulation diversity for tomato was at least three times lower than it was for alfalfa, pepper, and weeds and than between-subpopulation diversities, suggesting that tomato subpopulation was highly homogeneous $\left(K_{\mathrm{ST}}=0.114\right.$ and 0.148 for the MP and CP regions, respectively; $P<0.001$ ) (Supplemental Table 2). In fact, the only two haplotypes found in tomato showed type IIB in these regions. Moreover, evidence of genetic differentiation was found when subpopulations were distributed according to the geographic origin (Supplemental Table 3). For the P1 region, withinsubpopulation diversity for the Ebro Valley was slightly lower than for Ampurdán and than between-subpopulation diversity $\left(K_{\mathrm{ST}}=0.023, P=0.038\right)$ whereas, for the MP and CP regions, within-subpopulation diversity for Ampurdán was two to three times lower than for the Ebro Valley and than betweensubpopulation diversity $\left(K_{\mathrm{ST}}=0.091\right.$ and 0.095 for MP and CP, respectively; $P \leq 0.003$ ). This became evident because only haplotypes showing type $\mathrm{I}$ in these regions were present in

TABLE 2. Differences in amino acid residues among Alfalfa mosaic virus (AMV) phylogenetic types in the P1 and coat protein (CP) deduced partial protein sequences

\begin{tabular}{|c|c|c|c|c|c|c|c|c|}
\hline \multirow[b]{2}{*}{ Type $^{a}$} & \multicolumn{8}{|c|}{ Amino acid position } \\
\hline & 501 & 504 & 67 & 84 & 87 & 93 & 94 & 176 \\
\hline \multicolumn{9}{|l|}{ P1 } \\
\hline I & $\mathrm{A} / \mathrm{T}$ & $\mathrm{H}$ & $\ldots$ & $\ldots$ & $\ldots$ & $\ldots$ & $\ldots$ & $\ldots$ \\
\hline \multicolumn{9}{|l|}{$\mathrm{CP}$} \\
\hline I & $\ldots$ & $\ldots$ & F & $\mathrm{G}$ & I & $\mathrm{I} / \mathrm{N}$ & Y & $\mathrm{Q} / \mathrm{H}$ \\
\hline IIA & $\ldots$ & $\ldots$ & $S$ & A & I & $\mathrm{I} / \mathrm{V}$ & $\mathrm{F}$ & $\mathrm{L} / \mathrm{Q}$ \\
\hline
\end{tabular}

a Analyzed sequences corresponded to positions 360 to 587 of the 1,126 amino acids of the P1 protein and position 56 to 186 of the 222 amino acids of the CP protein, according to AMV strain 425L (GenBank accession numbers L00163 and K03542, respectively).
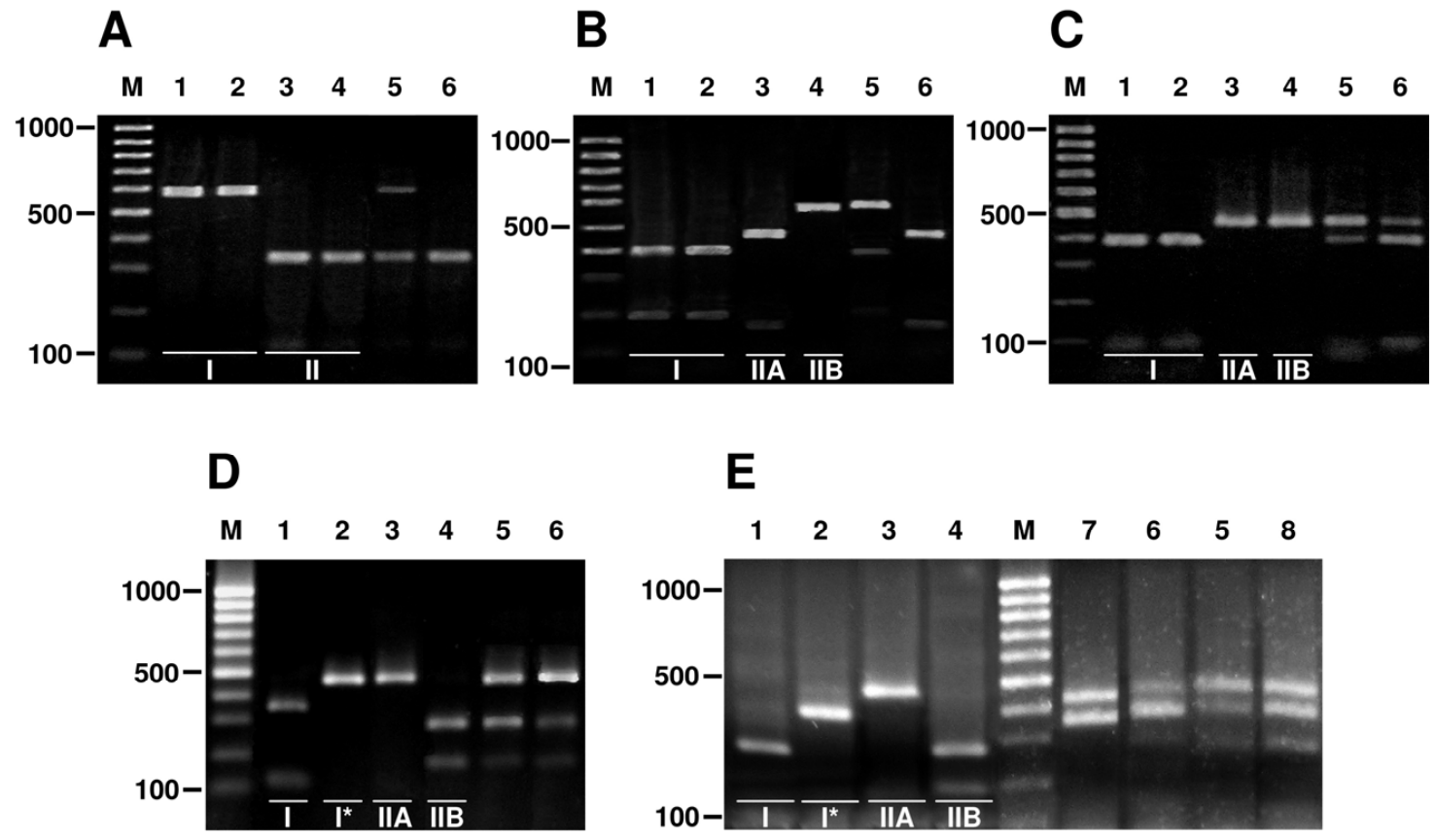

Fig. 2. Restriction fragment length polymorphism analyses of the A, P1 product digested with $T s p \mathrm{RI}$; B, movement protein product with $D d e \mathrm{I}$; and coat protein product with C, AvaII; D, SfaNI; and E, AvaII + SfaNI. Patterns for haplotypes I-I-I: AMV-425L (lane 1) and P-31-82.BAD (lane 2); II-IIA-IIA: P-46-02.EV (lane 3); II-IIB-IIB: P-62-84.EV (lane 4); and for isolates P.e-1-06.EV (lane 5) and Alf-8-05.EV (lane 6) are shown. In D and E, two different patterns were observed for AMV-425L (I) and P-31-82.BAD (I*). In E, mixes of P-31-82.BAD plus P-46-02.EV (I*+IIA, lane 7), and both plus P-62-84.EV (I*+IIA+IIB, lane 8) were loaded. The size of DNA-marker bands (lane $\mathrm{M}$ ) is indicated in base pairs. 
Ampurdán, whereas all haplotypes were present in the Ebro Valley. Genetic differentiation between these areas was also found when genetic diversity was analyzed exclusively with alfalfa isolates $\left(K_{\mathrm{ST}}=0.128\right.$ and 0.126 for MP and CP, respectively; $\left.P \leq 0.004\right)$.

To compare the genetic structure of the Spanish AMV population with that of AMV populations from other areas of the world, we analyzed the geographic distribution of nucleotide diversity in the AMV population worldwide based on the fragment of the $\mathrm{CP}$ region, the one with the largest number of available sequences. We considered as subpopulations the countries with at least three isolates. In total, 10 subpopulations from Europe, North America, Oceania, and Asia were analyzed. Genetic diversity values within and between these subpopulations are shown in Table 5. France, Italy, Serbia, Canada, Australia, and Korea showed low within-population diversities of 0.015 to 0.025 , and consisted of isolates of only one genetic type (I or IIA) (Fig. 1C). In contrast, Spain, New Zealand, England, and the United States, with isolates of at least two different genetic types, had nearly twice the within-population diversities, ranging from 0.036 to 0.050 , close to the value of total world diversity, 0.043 . Populations from Spain and New Zealand are, to date, the only two with isolates of all three types (I, IIA, and IIB). In general, within-population diversity values were lower or equal to between-population values (from 0.021 to 0.075 ), suggesting population differentiation. Geographic differentiation among AMV populations at world scale was confirmed $\left(K_{\mathrm{ST}}=0.198, P<\right.$ $0.001)$.

\section{DISCUSSION}

In the present article, we provide an analysis of the diversity and genetic structure of AMV populations in Spain, based on a collection of 60 isolates sampled from different hosts and geographic areas and, thus, representing different agroecological conditions. We also compare the Spanish population with AMV populations over the world, extending the analysis to sequences previously reported in genetic databases. Only a few studies on the genetic characterization of AMV isolates have been done, and all of them considered exclusively the amino acid or nucleotide sequence of the $\mathrm{CP}$ gene from a limited number of isolates $(33,58,75)$. In our study, we opted for increasing the number of isolates and analyzing the nucleotide sequence of partial regions randomly selected from the four ORFs of P1, P2, MP, and CP proteins, thus allowing the identification of reassortment and recombination events, which can be an important source of genetic variation.

The overall genetic diversity of the Spanish population was low (Table 1) compared with populations of other plant viruses, indicating that the AMV population was genetically stable (23). The genetic diversity and the degree of selective constraints against amino acid changes in the coding regions (as estimated by the ratio $\mathrm{dNS} / \mathrm{dS}<1$ ) differed among the four genomic regions, similarly to that shown for other plant viruses $(21,37,65)$.

In spite of the low genetic diversity of the Spanish AMV population, phylogenetic analysis in the $\mathrm{P} 1, \mathrm{MP}$, and $\mathrm{CP}$ genomic

TABLE 3. Analysis of reassortment or recombination of Alfalfa mosaic virus sequences showing phylogenetic incongruence

\begin{tabular}{|c|c|c|c|c|c|c|}
\hline \multirow[b]{2}{*}{ Group } & \multirow[b]{2}{*}{ Isolate } & \multirow[b]{2}{*}{ RDP analysis ${ }^{\mathrm{a}}$} & \multirow[b]{2}{*}{ Score ${ }^{b}$} & \multicolumn{3}{|c|}{ Clustering for each region ${ }^{c}$} \\
\hline & & & & $\mathrm{P} 1$ & MP & $\mathrm{CP}$ \\
\hline 1 & Alf-1-06-EV, T-7-05-EV, T-9-05-EV, T-4-07-EV & RGCMBS $\left(3.8 \times 10^{-3}-1.4 \times 10^{-7}\right)$ & 0.99 & Type I & Type IIB & Type IIB \\
\hline 2 & $\mathrm{~T}-12-05-\mathrm{EV}$ & RGCMBS $\left(1.2 \times 10^{-2}-1.7 \times 10^{-5}\right)$ & 0.74 & Type I & Type IIB & Type IIB \\
\hline 3 & $\begin{array}{l}\text { Alf-2-07-EV, T.r.-3-06-EV, Alf-1-04-EV, Alf-7-07-AM, Alf-8-07- } \\
\text { AM, Alf-28-05-EV, P-5-07-EV, C.s.-1-06-EV, Alf-24-05-EV }\end{array}$ & RGCMBS $\left(4.6 \times 10^{-3}-3.2 \times 10^{-5}\right)$ & 0.68 & Type II & Type I & Type I \\
\hline 4 & Alf-8-05-EV & RGCMBS $\left(2.6 \times 10^{-4}-7.3 \times 10^{-8}\right)$ & 0.65 & Type II & Type IIA & Type I \\
\hline 5 & Alf-14-05-EV & $\operatorname{CS}\left(1.5 \times 10^{-3}-2.9 \times 10^{-4}\right)$ & 0.53 & Type II & Type I & Type I \\
\hline \multicolumn{7}{|c|}{$\begin{array}{l}\text { analysis was performed on the concatenated alignment of P1, MP, and CP genomic regions using the RDP3 software. Methods supporting significant } \\
\text { recombination or reassortment signals are indicated together with the range of significance }(P \text { values) obtained: R (RDP), G (GENECONV), C (Chimaera), M } \\
\text { (MaxChi), B (BOOTSCAN), and S (SISCAN). }\end{array}$} \\
\hline \multicolumn{7}{|c|}{$\begin{array}{l}\text { b A recombinant score }>60 \% \text { indicates that the identified sequence is almost certainly the recombinant while a score between } 40 \text { and } 60 \% \text { indicates a reasonable } \\
\text { likelihood that the recombinant was accurately identified. }\end{array}$} \\
\hline
\end{tabular}

TABLE 4. Genetic structure of the Spanish Alfalfa mosaic virus population according to the host and geographic origin of isolates

\begin{tabular}{|c|c|c|c|c|c|c|c|c|c|c|}
\hline & & & \multicolumn{7}{|c|}{ Haplotypes $^{\mathrm{a}}$} & \multirow[b]{5}{*}{ Total } \\
\hline & & & 1 & 2 & 3 & 4 & 5 & 6 & 7 & \\
\hline & & $\mathrm{P} 1$ & I & II & II & II & $\mathrm{I}$ & II & $\mathrm{I}+\mathrm{II}$ & \\
\hline \multicolumn{2}{|c|}{ Origin of isolates } & MP & I & IIA & IIB & I & IIB & IIA & $\mathrm{I}+\mathrm{IIB}$ & \\
\hline Host & Area $^{\mathrm{b}}$ & $\mathrm{CP}$ & $\mathrm{I}$ & IIA & IIB & I & IIB & $\mathrm{I}+\mathrm{IIA}+\mathrm{IIB}$ & $\mathrm{I}+\mathrm{IIA}+\mathrm{IIB}$ & \\
\hline \multirow[t]{2}{*}{ Alfalfa } & $\mathrm{EV}$ & $\ldots$ & 4 & - & 7 & 5 & 1 & 1 & - & 18 \\
\hline & $\mathrm{AM}$ & $\ldots$ & 7 & - & - & 2 & - & - & - & 9 \\
\hline Total & $\ldots$ & $\ldots$ & 11 & - & 7 & 7 & 1 & 1 & - & 27 \\
\hline \multirow[t]{3}{*}{ Pepper } & BAD & $\ldots$ & 1 & 1 & - & - & - & - & - & 2 \\
\hline & LE & $\ldots$ & 2 & - & - & - & - & - & - & 2 \\
\hline & EV & $\ldots$ & - & 1 & 2 & 1 & - & - & - & 4 \\
\hline Total & $\ldots$ & $\ldots$ & 3 & 2 & 2 & 1 & - & - & - & 8 \\
\hline Tomato & EV & $\ldots$ & - & - & 6 & - & 4 & - & - & 10 \\
\hline Borage & EV & $\ldots$ & 1 & - & - & - & - & - & - & 1 \\
\hline Faba bean & EV & $\ldots$ & 1 & 1 & - & - & - & - & - & 2 \\
\hline \multirow[t]{4}{*}{ Weeds } & $\mathrm{EV}$ & $\ldots$ & 6 & - & 3 & 2 & - & - & 1 & 12 \\
\hline & EV, Total & $\ldots$ & 12 & 2 & 18 & 8 & 5 & 1 & 1 & 47 \\
\hline & AM, Total & $\ldots$ & 7 & - & - & 2 & - & - & - & 9 \\
\hline & EV+AM+ BAD+LE, Total & $\ldots$ & 22 & 3 & 18 & 10 & 5 & 1 & 1 & 60 \\
\hline
\end{tabular}

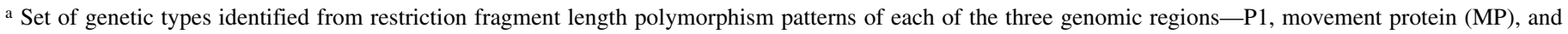
coat protein $(\mathrm{CP})$ - for which phylogenetic divergence was observed.

b Geographic areas: Ebro Valley (EV), Ampurdán (AM), Badajoz (BAD), and León (LE). 
regions of the 60 Spanish isolates showed that they diverged into two genetic types (I and II). This was in accordance with previous genetic studies based on sequences of the CP ORF of 26 AMV isolates from Europe, Asia, and North America $(58,75)$. In addition, MP and CP sequences of genetic type II further diverged into subtypes IIA and IIB. In contrast, there was no genetic subdivision for the $\mathrm{P} 2$ region. Although this result agrees with the low genetic diversity found in that region, it could also be due, in part, to the fact that the P2 gene was only analyzed partially. However, the fragment analyzed here does not correspond to either the conserved polymerase domain (60) or the N-terminal part of the protein required for the interaction between P1 and P2 during replication (72); consequently, it should not be expected that it was less polymorphic than the rest of the gene. Moreover, the inspection of polymorphic amino acid residues in those isolates for which the full-length protein is available in GenBank did not lead to similarities among isolates different than those derived from our partial analysis. Thus, the lack of genetic subdivision in the $\mathrm{P} 2$ region between types $\mathrm{I}$ and II, in contrast to what is shown in the three remaining genes, suggests that it follows different evolutionary dynamics.

Robustness of the observed phylogenetic subdivision in P1 and $\mathrm{CP}$ regions is supported by the existence of residues that are specific for each genetic type. In the analyzed fragment of P1, which is not included in either of the two conserved N-terminal methyltransferase and $\mathrm{C}$-terminal helicase domains of the protein (74), two residues were found not reported to date that distinguished between types I and II. In the CP, previous works had already reported variability for residues at positions 67,84 , and 94, which distinguish types IIA and IIB from type I, and at position 176, which differentiate type IIB from type I and the most part of type IIA $(51,58,70)$. The changes of the residues phenylalanine by serine at position 67 and glutamine by leucine at position 176 in the CP of strains VRU and 15/64, respectively, both belonging to type IIA, were involved in the formation of abnormally long particles that characterizes both strains (70). Both residue changes were found in all isolates from Spanish types IIA and IIB, except in two isolates of type IIA, which conserved the glutamine at position 176, and two isolates of type $\mathrm{IIB}$, in which the leucine at position 176 was replaced for a methionine. Thus, it is likely that most of the isolates belonging to these types produce abnormally long particles. In addition, we also found that the isoleucine at position 87 was replaced by a leucine in all type IIB isolates, suggesting that type IIB is more distant to type I than type IIA. Interestingly, isoleucine-87 and arginine- 86 are involved in the encapsidation of viral RNA and cell-to-cell transport but not in the genome activation and plusstrand RNA synthesis $(68,73)$. When complete CP sequences available in GenBank were examined, no additional residues were found outside of our analyzed fragment that were specific to any of the three genetic types.

In the analyzed region of MP protein, and despite divergence into three types found by the phylogenetic analysis, no specific residues were found that fully correlated with each type, which is in agreement with the high degree of constriction to amino acid changes estimated from the dNS/dS ratio for this region. The MP has been described as a highly conserved protein among several members of the family Bromoviridae, including AMV and ilarviruses, particularly in the first and middle part of the protein, with most of its variability located in the last 30 to 50 amino acids $(3,9,17,20,26)$. This conserved region contains important functional domains, some of them included in the fragment analyzed in this work: an RNA binding motif with high proportion of basic residues, identified in AMV and Prunus necrotic ringspot virus (PNRSV) $(27,43,64)$; a transmembrane region highly conserved in the " $30 \mathrm{~K}$ " superfamily of viral MPs (43); and part of the region required for tubule formation (63). Interestingly, most MPsequences belonging to genetic type IIB exchanged one of the eight basic residues in the RNA binding domain, lysine at position 72, by arginine. Recently, three new sequences of AMVRNA3 from New Zealand have been reported in GenBank, which belong to types IIA (isolate 175) and IIB (isolates 176 and 178) according to our phylogenetic analysis (Fig. 1B and C). When MP sequences from these isolates were examined together with 11 other complete MP sequences of types I and IIA, additional amino acid changes that discriminate between type I and types IIA and IIB were observed outside of our analyzed fragment, particularly in the C-terminal part of the protein $(\mathrm{M}>\mathrm{I}$, $\mathrm{S} / \mathrm{N}>\mathrm{K} / \mathrm{R} / \mathrm{G}, \mathrm{P}>\mathrm{L} / \mathrm{F}$, and $\mathrm{S}>\mathrm{G}$ at positions $13,230,256$, and 257, respectively), with arginine at position 72 being the only amino

TABLE 5. Nucleotide diversities for the coat protein (CP) region within and between Alfalfa mosaic virus (AMV) populations from the same country

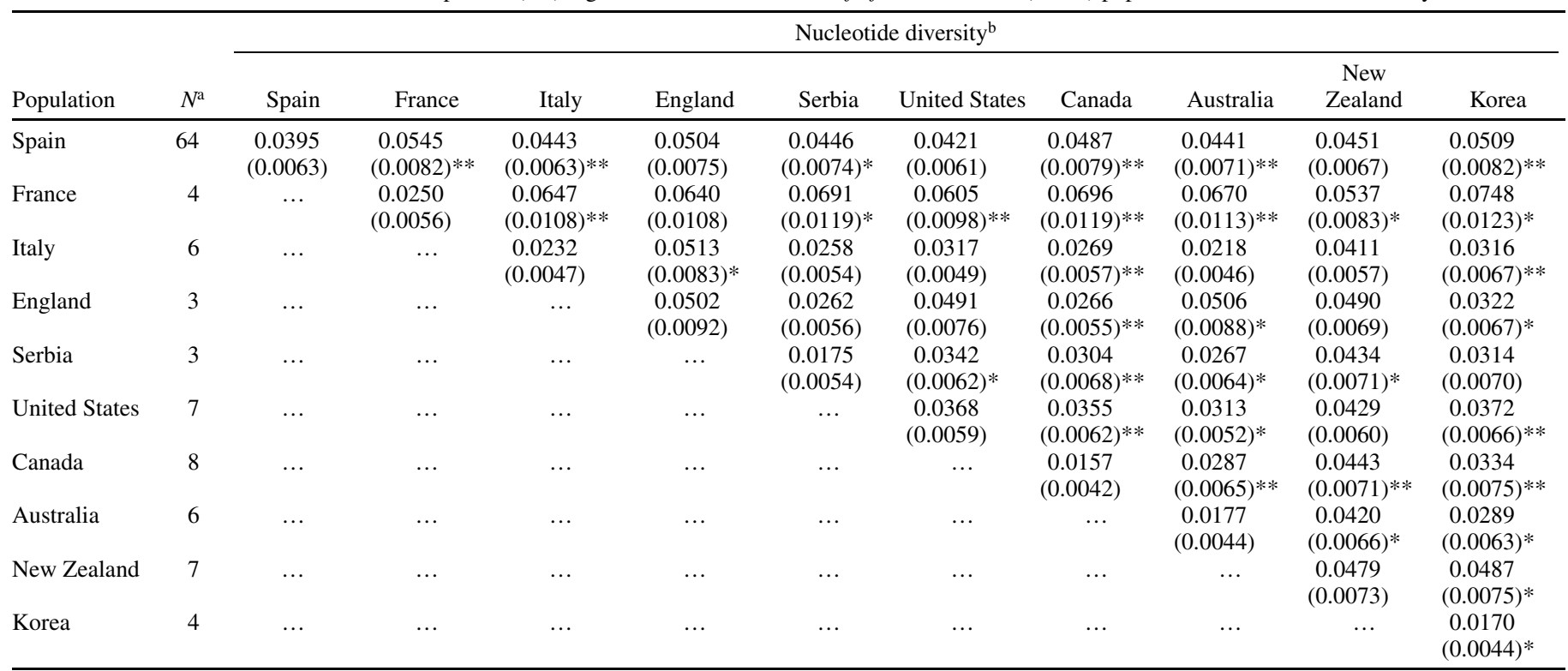

\footnotetext{
${ }^{a}$ Number of AMV isolates in each analyzed population.

${ }^{\mathrm{b}}$ Nucleotide diversities within (main diagonal) and between populations according to the Kimura's two-parameter method, expressed as the mean number of nucleotide substitutions per site. Standard errors are indicated in brackets. Asterisks indicate significance for $K_{\mathrm{ST}}(* *$ and $*$ indicate $P<0.01$ and 0.05 , respectively) in pairwise comparisons between populations.
} 
acid change completely specific for type IIB. This also supports the divergence into the three genetic types observed in our phylogenetic analysis, based on partial nucleotide sequences.

In the preceding text, we have discussed amino acid variations located in sequence fragments of the $\mathrm{P} 1, \mathrm{MP}$, and $\mathrm{CP}$ proteins, which characterize the observed three genetic types. However, it is possible that beneficial or deleterious effects could be expected from the combination of these mutations or with other mutations outside of the fragments analyzed, due to the fact that most mutations in virus genomes show antagonistic epistasis (8). It would be interesting to obtain the complete sequence of these proteins in a number of isolates of each different genetic type to explore this issue.

Recently, Parrella et al. (56) reported the subdivision of type II and invoked a novel genetic type based on the CP ORF of a single Spanish isolate from Tecoma capensis (Tec-1). Later, four additional isolates from ornamental species were assigned to this novel type (57). In our analysis, four of these isolates (TM-2, Tec1, Phlox paniculata, and VIRB) clustered with type IIA (the original type II) regardless of the region considered (MP or $\mathrm{CP}$ ) (Fig. 1B and C). Only the isolate CV-1 (57) clustered with our type IIB and contained the $\mathrm{CP}$ amino acid residues specific to this type. To date, the new genetic type IIB is exclusively composed of several Spanish isolates and two isolates from New Zealand. Similarly, type IIA mostly contains isolates from Europe.

Haplotypes present in the Spanish AMV population were deduced from phylogenetic analysis and confirmed for most isolates by RFLP analysis with four restriction endonucleases. RFLP analysis was necessary to unequivocally detect the presence or absence of mixed infections in the field samples and correctly interpret genetic information obtained from regions amplified independently by RT-PCR as part of the same individual (what we call here a haplotype). We preferred this method instead of systematic biological cloning to have an estimate of the frequency of mixed infections in the field and because not every single AMV isolate is biologically cloned easily in a local-lesion host. Then, biological cloning was exclusively used to further characterize mixed-infection haplotypes and for RFLP control isolates. Seven different haplotypes were identified: the three most frequent nonreassortant haplotypes (72\%), two relatively frequent reassortant haplotypes $(25 \%)$, and two others corresponding to infrequent mixed infections (3\%). Mixed infections might involve recombinant sequences. In particular, haplotype 6 (isolate Alf-805.EV) should involve a mix of haplotypes: II-IIA-IIA and two putative recombinants in RNA3, II-IIA-I, and II-IIA-IIB.

Distribution of haplotypes in the Spanish AMV population was not uniform, indicating a genetic structure according to the host and geographic origin of isolates. Indeed, genetic structure differed for the tomato subpopulation, with only haplotypes of type IIB in both regions of RNA3. However, genetic differentiation in tomato could not to be strictly associated with this host because (i) genetic diversity in the tomato subpopulation was similar to that found within cluster IIB (0.0123 for MP, 0.0156 for CP), which also includes isolates from other hosts; and (ii) tomato isolates belonging to types I and IIA (195-AN, Da, and Lye-80) (Fig. 1C) have been already reported for the $\mathrm{CP}$ region (58). A larger number of tomato isolates should be characterized to clarify this question. Geographic differentiation of AMV populations was previously reported from the $\mathrm{CP}$ analysis of up to 26 isolates from Europe, Asia, and North America $(58,75)$. Here, we have extended this analysis to 112 isolates, providing genetic diversity data within and between subpopulations from 10 different countries and confirming the existence of genetic differentiation among them. Genetic population structure found for AMV contrasts with that of the ilarviruses PNRSV and American plum line pattern virus $(3,17,26,54)$, in which no correlation between genetic differences and geographic origin of isolates was found. For AMV, (i) genetic type I is present as a single type in most world regions; and ii) types IIA and IIB are only present in some European countries (France, England, and Spain), except for an isolate from $P$. paniculata from the United States (IIA) (this work; 75) and three others from Actinidia spp. from New Zealand (IIA and IIB), which were probably introduced there from Europe through exchange of plant material.

Remarkably, genetic differentiation was also observed in Spain between its two main agroecological areas, Ebro Valley and Ampurdán. Although the most frequent haplotypes (haplotypes 1, 3, 4, and 5) are present in Ebro Valley, haplotypes 3 and 5 are not found in Ampurdán. The fact that, in Ampurdán, type II is only found in RNA1 of the reassortant haplotype 4 and not in any nonreassortant haplotype suggests that this reassortant could be directly introduced there from another area, being maintained in the population afterward. Also, note that reassortant haplotypes 4 and 5 seem to have followed different epidemiological dynamics, as suggested by recombination analysis. Haplotype 5 was explained by two independent reassortment events (Table 3, groups 1 and 2), in which only isolates from alfalfa and mostly from tomato were represented (3.7 and $30 \%$ of total alfalfa and tomato isolates, respectively), the latter ones probably overestimated, because some of them (T-7-05.EV, T-9.05.EV, and T-12-05.EV) were collected in the same epidemic event in Zaragoza (not shown). This could mean that haplotype 5 was generated sporadically and was not maintained in the AMV population. In contrast, haplotype 4 is mostly explained by a single reassortment event, (Table 3, group 3), with reassortants found with relatively high frequencies in alfalfa, pepper, and weeds (12 to $22 \%$ ) and collected in two different geographic areas over the period 2004 to 2007. This strongly suggests that haplotype 4 is maintained in the AMV population.

Reassortants occur naturally in populations of plant viruses with segmented genomes $(7,19,37,47,69)$ but at rather low frequencies. For Cucumber mosaic virus (CMV), which is, like AMV, nonpersistently aphid transmitted, selection against genetic exchange has been reported in favor of gene coadaptation $(15,19)$. In the absence of any information on the relative fitness of the AMV haplotypes found here, we discuss the differences between the population dynamics of both viruses. CMV populations fluctuate at random, showing a metapopulation structure, which is explained by population bottlenecks during virus or vector extinction at the end of vegetable crops and recolonization from reservoirs $(19,22)$. In contrast, our results show that the most frequent haplotypes are maintained within AMV subpopulations, including at least one of those originated by reassortment, contributing to the maintenance of genetic differences among agroecological areas. AMV is seedborne in alfalfa, and infected seed is probably the main source of primary inoculum $(25,30)$. Moreover, alfalfa is a perennial host species that remains several years in the field, allowing the overlapping of AMV populations in alfalfa and in other adjacent crops. Early establishment of preexisting genetic types from infected seed and overlapping of populations, which prevented the occurrence of genetic bottlenecks, may have contributed to the maintenance of AMV genetic structure, as reported for other plant virus populations $(1,34,41)$. On the other hand, alfalfa landraces have been traditionally cultivated in Spain, which are well adapted to the specific environments of different geographic areas (12). Landrace 'Ampurdán' is restricted to this area and its seed has been traditionally produced by farmers on their own. However, seed of landrace 'Aragon', adapted to the Ebro Valley, is frequently produced in different areas under certification programs, promoting the commercial seed exchange (2). Seed exchange could have also been favored during the development of breeding programs in the 1970s, when alien alfalfa seed was introduced in Europe, mainly from North America and Australia (i.e., 'Artal' and 'Hunter River'). This was the case in the Ebro Valley in Spain (38) and might have led to its increased genetic variability compared with Ampurdán. 
In this work, we have presented what is, to our knowledge, the most comprehensive study of AMV populations reported to date, based on genetic information covering genes from the three AMV genomic segments, which has led to the first detection in Spain of reassortant and recombinant sequences originated in natural conditions. The Spanish population is as diverse as the total world population and, to date, is one of the only two that present the third novel phylogenetic type IIB. The maintenance of the main genetic types and their geographic distribution point to agroecological factors as potential determinants of the evolution and epidemiological dynamics of AMV. These results are also relevant to the role of alfalfa as an AMV inoculum reservoir for other adjacent susceptible crops, such as many important vegetables.

\section{ACKNOWLEDGMENTS}

This work was supported by grant RTA04-037-C2-1, Instituto Nacional de Investigación y Tecnología Agraria y Alimentaria (INIA), Madrid, Spain. M. Bergua was in receipt of a fellowship of Formación de Personal Investigador from INIA. We thank J. F. Bol and L. Neeleman, Institute of Biology, Leiden University, Leiden, The Netherlands, for generously providing AMV strains $425 \mathrm{~L}$ and YSMV used as references; and M. M. López-Bordonaba and M. C. Pasamar for excellent technical assistance.

\section{LITERATURE CITED}

1. Achon, M. A., Alonso-Dueñas, N., and Serrano, L. 2011. Maize dwarf mosaic virus diversity in the Johnsongrass native reservoir and in maize: Evidence of geographical, host and temporal differentiation. Plant Pathol. 60:369-377.

2. Álvaro, J., and Lloveras, J. 2003. Metodología de la producción de alfalfa en España. Asociación Interprofesional de Forrajes Españoles y Ministerio de Agricultura, Pesca y Alimentación, Lleida, Spain.

3. Aparicio, F., and Pallás, V. 2002. The molecular variability analysis of the RNA3 of fifteen isolates of Prunus necrotic ringspot virus sheds light on the minimal requirements for the synthesis of its subgenomic RNA. Virus Genes 25:75-84.

4. Bancroft, J. B., Moorhead, E. L., Tuite, J., and Liu, H. P. 1960. The antigenic characteristics and the relationship among strains of Alfalfa mosaic virus. Phytopathology 50:34-39.

5. Bergua, M., Vargas-Mainar, M. E., Muñoz, F., Delgado-Enguita, I., LuisArteaga, M., and Escriu, F. 2008. El virus del mosaico de la alfalfa en zonas productoras de alfalfa españolas. Page 233 in: XIV Congr. Soc. Esp. Fitopatol. Sociedad Española de Fitopatología y Consellería do Medio Rural Xunta de Galicia, Lugo, Spain.

6. Bol, J. F. 2005. Replication of alfamo- and ilarviruses: Role of the coat protein. Annu. Rev. Phytopathol. 43:39-62.

7. Bonnet, J., Fraile, A., Sacristán, S., Malpica, J. M., and García-Arenal, F. 2005. Role of recombination in the evolution of natural populations of Cucumber mosaic virus, a tripartite RNA plant virus. Virology 332:359368.

8. Carrasco, P., de la Iglesia, F., and Elena, S. 2007. Distribution of fitness and virulence effects caused by single-nucleotide substitutions in Tobacco etch virus. J. Virol. 81:12979-12984.

9. Codoñer, F. M., Cuevas, J. M., Sánchez-Navarro, J. A., Pallás, V., and Elena, S. F. 2005. Molecular evolution of the plant virus family Bromoviridae based on RNA3 encoded proteins. J. Mol. Evol. 61:697705.

10. Crill, P., Hagedorn, D. J., and Hanson, E. W. 1971. An artificial system for differentiating strains of Alfalfa mosaic virus. Plant Dis. 55:127-130.

11. Delgado-Enguita, I., and Luna-Calvo, M. L. 1992. Incidence of virus disease in isolated plants of lucerne in the N-E of Spain. Pages 302-302 in: The Future of Lucerne Biotechnology, Breeding and Variety Constitution. Proc. X Int. Conf. EUCARPIA Medicago spp. Group. P. Rotili and L. Zannone, eds. Instituto Sperimentale per la Colture Forraggere, Lodi, Italy.

12. Del Pozo, M. 1983. La alfalfa. Su cultivo y aprovechamiento, 3rd ed. Ediciones Mundi-Prensa, Madrid.

13. Díaz-Ruiz, J. R., and Moreno, R. 1972. Symptomatologic, morphologic and ultrastructural characteristics of a strain of Alfalfa mosaic virus found in Spain. Microbiol. Esp. 25:127-140.

14. Edwardson, J. R., and Christie, R. G. 1997. Alfamovirus Genus. Alfalfa mosaic virus species. Pages 63-94 in: Viruses Infecting Peppers and Other Solanaceous Crops. Monogr. 18-I. University of Florida Press, Gainesville.

15. Escriu, F., Fraile, A., and García-Arenal, F. 2007. Constraints to genetic exchange support gene coadaptation in a tripartite RNA virus. PLoS
Pathog. 3:67-74

16. FAO. 2011. Faostat. http://faostat.fao.org/site/339/default.aspx

17. Fiore, N., Fajardo, T. V. M., Prodan, S., Herranz, M. C., Aparicio, F., Montealegre, J., Elena, S. F., Pallás, V., and Sánchez-Navarro, J. 2008. Genetic diversity of the movement and coat protein genes of South American isolates of Prunus necrotic ringspot virus. Arch. Virol. 153:909-919.

18. Fitch, W. M. 1977. Problem of discovering most parsimonious tree. Am. Nat. 111:223-257.

19. Fraile, A., Alonso-Prados, J. L., Aranda, M. A., Bernal, J. J., Malpica, J. M., and García-Arenal, F. 1997. Genetic exchange by recombination or reassortment is infrequent in natural populations of a tripartite RNA plant virus. J. Virol. 71:934-940.

20. Galipienso, L., Rubio, L., López, C., Soler, S., and Aramburu, J. 2009. Complete nucleotide sequence of a Spanish isolate of Parietaria mottle virus infecting tomato. Virus Genes 39:256-260.

21. García-Andrés, S., Accotto, G. P., Navas-Castillo, J., and Moriones, E. 2007. Founder effect, plant host, and recombination shape the emergent population of begomoviruses that cause the tomato yellow leaf curl disease in the Mediterranean basin. Virology 359:302-312.

22. García-Arenal, F., Escriu, F., Aranda, M. A., Alonso-Prados, J. L., Malpica, J. M., and Fraile, A. 2000. Molecular epidemiology of Cucumber mosaic virus and its satellite RNA. Virus Res. 71:1-8.

23. García-Arenal, F., Fraile, A., and Malpica, J. M. 2001. Variability and genetic structure of plant virus populations. Annu. Rev. Phytopathol. 39:157-186.

24. Gibbs, A., Gibbs, M. J., Ohshima, K., and García-Arenal, F. 2008. More about plant virus evolution: Past, present, and future. Pages 229-250 in: Origin and Evolution of Viruses, 2nd ed. E. Domingo, C. R. Parrish, and J. J. Holland, eds. Academic Press (Elsevier), London.

25. Hemmati, K., and McLean, D. L. 1977. Gamete seed transmission of Alfalfa mosaic virus and its effects on seed germination and yield in alfalfa plants. Phytopathology 67:576-579.

26. Herranz, M. C., Al Rwahnih, M., Sánchez-Navarro, J. A., Elena, S. F., Choueiri, E., Myrta, A., and Pallás, V. 2008. Low genetic variability in the coat and movement proteins of American plum line pattern virus isolates from different geographic origins. Arch. Virol. 153:367-373.

27. Herranz, M. C., and Pallás, V. 2004. RNA-binding properties and mapping of the RNA-binding domain from the movement protein of Prunus necrotic ringspot virus. J. Gen. Virol. 85:761-768.

28. Hiruki, C., and Hampton, R. O. 1990. Diseases caused by viruses and viruses infectious to alfalfa. Pages 51-58 in: Compendium of Alfalfa Diseases. D. L. Stuteville and D. C. Erwin, eds. American Phytopathological Society, St. Paul, MN.

29. Hudson, R. R., Boos, D. D., and Kaplan, N. L. 1992. A statistical test for detecting geographic subdivision. Mol. Biol. Evol. 9:138-151.

30. Jaspars, E. M. J., and Bos, L. 1980. Alfalfa mosaic virus. CMI/AAB Description of Plant Viruses, No. 229. Association of Applied Biologists, Warwick, UK.

31. Kimura, M. 1980. A simple method for estimating evolutionary rates of base substitutions through comparative studies of nucleotide sequences. J. Mol. Evol. 16:111-120.

32. Knorr, D. A., Laemmlen, F. F., and Dawson, W. O. 1983. Effects of a necrosis inducing isolate of Alfalfa mosaic virus on stand loss in tomatoes. Phytopathology 73:1554-1558.

33. Kraal, B. 1975. Amino acid analysis of Alfalfa mosaic virus coat proteins: An aid for viral strain identification. Virology 66:336-340.

34. Krause-Sakate, R., Le Gall, O., Fakhfakh, H., Peypelut, M., Marrakchi, M., Varveri, C., Pavan, M. A., Souche, S., Lot, H., Zerbini, F. M., and Candresse, T. 2002. Molecular and biological characterization of Lettuce mosaic virus (LMV) isolates reveals a distinct and widespread type of resistance-breaking isolate: LMV-Most. Phytopathology 92:563-572.

35. Li, W. H. 1993. Unbiased estimation of the rates of synonymous and nonsynonymous substitution. J. Mol. Evol. 36:96-99.

36. Librado, P., and Rozas, J. 2009. DnaSP v5: A software for comprehensive analysis of DNA polymorphism data. Bioinformatics 25:1451-1452.

37. Lin, H. X., Rubio, L., Smythe, A. B., and Falk, B. W. 2004. Molecular population genetics of Cucumber mosaic virus in California: Evidence for founder effects and reassortment. J. Virol. 78:6666-6675.

38. Lloveras, J. 2001. Alfalfa (Medicago sativa L.) management for irrigated Mediterranean conditions: The case of the Ebro Valley. Pages 115-125 in: Quality in Lucerne and Medics for Animal Production. Proc. XIV Eucarpia Medicago spp. Group Meet. I. Delgado and J. Lloveras, eds. Instituto Agronómico Mediterráneo, Zaragoza.

39. Luis-Arteaga, M., Cambra, M., Arnedo-Andrés, M., Mallor, C., Sagrario, J., Escriu, F., and Gil Ortega, R. 2004. Etiología de las virosis en cultivos de pimiento al aire libre en León durante los años 2001, 2002 y 2003. Acta Hortic. 41:153-156.

40. Mallor, C., Luis-Arteaga, M., Cambra, M., and Fernández-Cavada, S. 2002. Natural infection of field-grown borage (Borago officinalis) by 
Alfalfa mosaic virus in Spain. Plant Dis. 86:698.

41. Marco, C. F., and Aranda, M. A. 2005. Genetic diversity of a natural population of Cucurbit yellow stunting disorder virus. J. Gen. Virol. 86:815-822.

42. Martin, D. P., Lemey, P., Lott, M., Moulton, V., Posada, D., and Lefeuvre, P. 2010. RDP3: A flexible and fast computer program for analyzing recombination. Bioinformatics 26:2462-2463.

43. Melcher, U. 2000. The ' $30 \mathrm{~K}$ ' superfamily of viral movement proteins. J. Gen. Virol. 81:257-266.

44. Milbrath, J. A., and McWhorter, F. P. 1953. The reaction of tomato varieties to various strains of Alfalfa mosaic virus. Phytopathology 43:479-479.

45. Milbrath, J. A., and McWhorter, F. P. 1954. Response of cowpea varieties to strains of Alfalfa mosaic virus. Phytopathology 44:498-498.

46. Milgroom, M. G., and Peever, T. L. 2003. Population biology of plant pathogens. The synthesis of plant disease epidemiology and population genetics. Plant Dis. 87:608-617.

47. Miranda, G. J., Azzam, O., and Shirako, Y. 2000. Comparison of nucleotide sequences between northern and southern Philippine isolates of Rice grassy stunt virus indicates occurrence of natural genetic reassortment. Virology 266:26-32.

48. Moreno, A., de Blas, C., Biurrun, R., Nebreda, M., Palacios, I., Duque, M., and Fereres, A. 2004. The incidence and distribution of viruses infecting lettuce, cultivated Brassica and associated natural vegetation in Spain. Ann. Appl. Biol. 144:339-346.

49. Moury, B., Desbiez, C., Jacquernond, M., and Lecoq, H. 2006. Genetic diversity of plant virus populations: Towards hypothesis testing in molecular epidemiology. Adv. Virus. Res. 67:49-87.

50. Mueller, E. E., Groves, R. L., and Gratton, C. 2012. Crop and non-crop plants as potential reservoir hosts of Alfalfa mosaic virus and Cucumber mosaic virus for spread to commercial snap bean. Plant Dis. 96:506-514.

51. Neeleman, L., van der Kuyl, A. C., and Bol, J. F. 1991. Role of Alfalfa mosaic virus coat protein gene in symptom formation. Virology 181:687693.

52. Nei, M. 1987. Molecular Evolutionary Genetics. Columbia University Press, New York.

53. Nei, M., and Kumar, S. 2000. Molecular Evolution and Phylogenetics. Oxford University Press, New York.

54. Oliver, J. E., Freer, J., Andersen, R. L., Cox, K. D., Robinson, T. L., and Fuchs, M. 2009. Genetic diversity of Prunus necrotic ringspot virus isolates within a cherry orchard in New York. Plant Dis. 93:599-606.

55. Pamilo, P., and Bianchi, N. O. 1993. Evolution of the Zfx and Zfy genes: Rates and interdependence between the genes. Mol. Biol. Evol. 10:271281.

56. Parrella, G., Acanfora, N., Orílio, A., and Navas-Castillo, J. 2011. Complete nucleotide sequence of a Spanish isolate of Alfalfa mosaic virus: Evidence for additional genetic variability. Arch. Virol. 156:1049-1052.

57. Parrella, G., Flallo-Olive, E., and Navas-Castillo, J. 2012. First report of China Rose (Hibiscus rosa-sinensis) as a host of Alfalfa mosaic virus in Spain. Plant Dis. 96:462-462.

58. Parrella, G., Lanave, C., Marchoux, G., Sialer, M. M., Di Franco, A., and Gallitelli, D. 2000. Evidence for two distinct subgroups of Alfalfa mosaic virus (AMV) from France and Italy and their relationships with other AMV strains. Arch. Virol. 145:2659-2667.
59. Peña-Iglesias, A. 1977. Catálogo de virus y microorganismos del tipo micoplasma y rickettsia identificados en plantas cultivadas en España. Ministerio de Agricultura, Madrid.

60. Poch, O., Sauvaget, I., Delarue, M., and Tordo, N. 1989. Identification of four conserved motifs among the RNA-dependent polymerase encoding elements. EMBO J. 8:3867-3874.

61. Saitou, N., and Nei, M. 1987. The neighbor-joining method: A new method for reconstructing phylogenetic trees. Mol. Biol. Evol. 4:406-425.

62. Sambrook, J., and Russell, D. W. 2001. Molecular Cloning: A Laboratory Manual. Cold Spring Harbor Laboratory, Cold Spring Harbor, NY.

63. Sánchez-Navarro, J. A., and Bol, J. F. 2001. Role of the Alfalfa mosaic virus movement protein and coat protein in virus transport. Mol. PlantMicrobe Interact. 14:1051-1062.

64. Schoumacher, F., Giovane, C., Maira, M., Poirson, A., Godefroycolburn, T., and Berna, A. 1994. Mapping of the RNA-binding domain of the Alfalfa mosaic virus movement protein. J. Gen. Virol. 75:3199-3202.

65. Seo, J. K., Ohshima, K., Lee, H. G., Son, M., Choi, H. S., Lee, S. H., Sohn, S. H., and Kim, K. H. 2009. Molecular variability and genetic structure of the population of Soybean mosaic virus based on the analysis of complete genome sequences. Virology 393:91-103.

66. Shah, D. A., Dillard, H. R., Mazumdar-Leighton, S., Gonsalves, D., and Nault, B. A. 2006. Incidence, spatial patterns, and associations among viruses in snap bean and alfalfa in New York. Plant Dis. 90:203-210.

67. Tamura, K., Dudley, J., Nei, M., and Kumar, S. 2007. MEGA4: Molecular evolutionary genetics analysis (MEGA) software version 4.0. Mol. Biol. Evol. 24:1596-1599.

68. Tenllado, F., and Bol, J. F. 2000. Genetic dissection of the multiple functions of Alfalfa mosaic virus coat protein in viral RNA replication, encapsidation and movement. Virology 268:29-40.

69. Tentchev, D., Verdin, E., Marchal, C., Jacquet, M., Aguilar, J. M., and Moury, B. 2011. Evolution and structure of Tomato spotted wilt virus populations: Evidence of extensive reassortment and insights into emergence processes. J. Gen. Virol. 92:961-973.

70. Thole, V., Miglino, R., and Bol, J. F. 1998. Amino acids of Alfalfa mosaic virus coat protein that direct formation of unusually long virus particles. J. Gen. Virol. 79:3139-3143.

71. Thompson, J. D., Gibson, T. J., Plewniak, F., Jeanmougin, F., and Higgins, D. G. 1997. The CLUSTAL_X windows interface: Flexible strategies for multiple sequence alignment aided by quality analysis tools. Nucleic Acids Res. 25:4876-4882.

72. van der Heijden, M. W., Carette, J. E., Reinhoud, P. J., Haegi, A., and Bol, J. F. 2001. Alfalfa mosaic virus replicase proteins P1 and P2 interact and colocalize at the vacuolar membrane. J. Virol. 75:1879:1887.

73. van der Vossen, E. A. G., Neeleman, L., and Bol, J. F. 1994. Early and late functions of Alfalfa mosaic virus coat protein can be mutated separately. Virology 202:891-903.

74. Vlot, A. C., Menard, A., and Bol, J. F. 2002. Role of the Alfalfa mosaic virus methyltransferase-like domain in negative-strand RNA synthesis. J. Virol. 76:11321-11328.

75. Xu, H., and Nie, J. 2006. Identification, characterization, and molecular detection of Alfalfa mosaic virus in potato. Phytopathology 96:12371242 .

76. Yang, Z., and Bielawski, J. P. 2000. Statistical methods for detecting molecular adaptation. Trends Ecol. Evol. 15:496-503. 